\title{
SISTEM PAKAR MENDETEKSI GANGGUAN OBSESSIVE COMPULSIVE DISORDER MENGGUNAKAN METODE BACKWARD CHAINING
}

\author{
${ }^{1}$ Hammas Zulfikar Ikhsan, ${ }^{2}$ Dr. Oky Dwi Nurhayati, S.T., M.T., ${ }^{3}$ Yudi Eko Windarto, S.T., \\ M.Kom. \\ ${ }^{1}$ Departemen Teknik Komputer Universitas Diponegoro \\ Semarang, Indonesia, e-mail: masham2121@gmail.com \\ 2 Departemen Teknik Komputer Universitas Diponegoro \\ Semarang, Indonesia, e-mail: okydwin@gmail.com \\ ${ }^{3}$ Departemen Teknik Komputer Universitas Diponegoro \\ Semarang, Indonesia, e-mail: yudi@live.undip.ac.id
}

\section{ARTICLE INFO}

Article history:

Received 20 Maret 2019

Received in revised form 01 July 2019

Accepted 25 July 2019

Available online 31 July 2019

\begin{abstract}
Obsessive compulsive disorder is a psychological disorder caused by anxiety and fear that appears suddenly. OCD can interfere daily activity to cause depression. In the process of diagnosis, patients use uncertain words such as "decent", "rare", "enough". This causes the doctor difficulty in making a diagnosis. From these problem, an expert system application was made that can detect obsessive compulsive disorder to facilitate and increase the level of trust of doctors in diagnosing. This application uses the method of backward chaining and certainty factor and uses PHP and MySQL languages. From this study, an expert system application was produced that can displays the results of the detection of the type of obsessive compulsive disorder. The results of application testing are in accordance with expert knowledge. Black box testing which shows all of application function that can run as expected.

Keywords - Obsessive Compulsive Disorder (OCD), Expert System, Backward Chaining, Certainty Factor, PHP
\end{abstract}

\section{Pendahuluan}

Obsessive Compulsive Disorder atau OCD adalah sebuah gangguan psikologi yang terbentuk dari dua sikap yakni obsesif dan kompulsif. Obsesif merupakan pemikiran yang muncul secara berulang yang menyebabkan kecemasan pada individu tanpa dapat dikendalikan. Sedangkan kompulsif adalah keinginan yang tidak bisa ditahan dari individu untuk melakukan sesuatu. ${ }^{[1]}$ Gangguan mental ini merupakan gejala kegelisahan yang luar biasa. Penyandang gangguan ini akan menampakkan gejala berupa sikap berlebihan dalam kehidupan sehari-hari. ${ }^{[1]}$

Secara garis besar gangguan Obsessive Compulsive Disorder dibagi menjadi tipe-tipe yang didasari dari tindakan dan obsesi dari penderita. Beberapa tipe gangguan Obsesive Compulsive Disorder antara lain : tipe checking ditunjukan dengan obsesi penderita untuk selalu memeriksa 
keadaan dari suatu benda secara berulang-ulang, tipe washing ditunjukan dengan obsesi penderita untuk selalu membersihkan diri dan lingkungannya secara berlebihan, tipe hoarding ditandai dengan obsesi penderita untuk selalu mengumpulkan dan menyimpan barang yang dimiliki, tipe symmetry orderliness ditandai dengan obsesi penderita untuk selalu mengatur posisi dari suatu benda hingga sejajar, urut dan simetris. ${ }^{[2]}$

Pada proses diagnosa gangguan obsessive compulsive disorder oleh dokter, pasien menggunakan jawaban yang tidak pasti seperti "jarang", "lumayan",dan "cukup" untuk menjawab pertanyaan yang diberikan oleh dokter. Oleh karena itu, sistem pakar ini dibuat agar dapat membantu dokter dalam meningkatkan tingkat kepercayaan dalam mendeteksi tipe gangguan obsessive compulsive disorder yang diderita oleh pasien.

Sistem pakar yang dapat mendeteksi gangguan Obsessive Compulsive Disorder pada seseorang ini menggunakan metode Backward Chaining. Metode Backward Chaining digunakan karena sistem diagnosa akan lebih efektif karena sistem akan memberikan pertanyaan yang berisi gejala berdasarkan hipotesis yang diberikan pada awal diagnosa dan metode ini memudahkan sistem untuk menghitung probabilitas karena sistem hanya menghitung satu hipotesis berdasarkan fakta yang dipilih. Metode Backward Chaining akan meminta user untuk memilih salah satu tipe dari gangguan Obsessive Compulsive Disorder yang kemungkinan besar diderita oleh penderita. Kemudian sistem akan memberikan pertanyaan yang berisi gejala dari tipe Obsessive Compulsive Disorder yang dipilih sebelumnya. Hasil dari pertanyaan akan diolah menggunakan rumus certainty factor untuk menghasilkan keluaran yang diinginkan. Keluaran yang diingkan dari system adalah user dapat mengetahui besar kemungkinan dideritanya tipe gangguan Obsessive Compulsive Disorder yang dipilih sebelumnya pada aplikasi.

\section{Metode Penelitian}

Penelitian ini menggunakan Expert System Development Cycle sebagai metode penelitian.

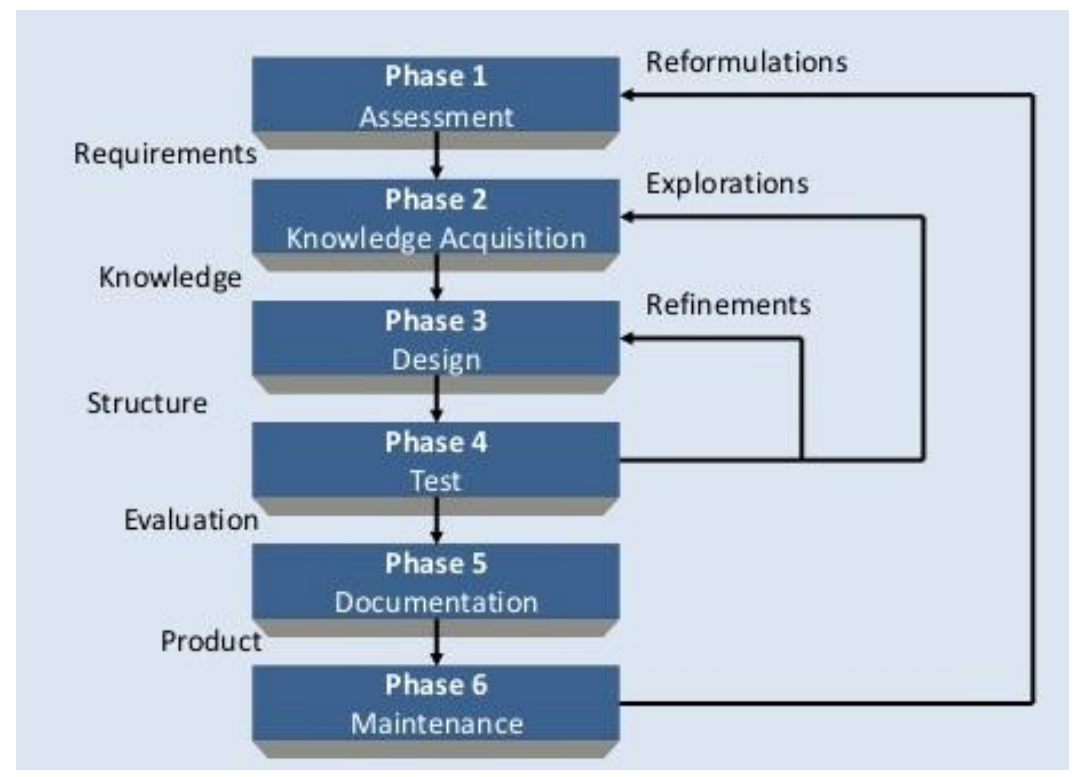

Gambar 1 Expert System Development Cycle

Dalam penelitian ini, aplikasi yang dibuat adalah aplikasi sistem pakar berbasis web yang dapat membantu pakar dalam mendapatka informasi, mendiagnosa dan membantu dalam memberi pertolongan pada pasien tentang gangguan yang diderita. Aplikasi ini berbasis web yang dapat diakses melalui komputer atau laptop pengguna. Dalam aplikasi ini pengguna bisa memanfaatkan beberapa fitur dari aplikasi sebagai berikut :

1. Melakukan diagnosa tentang gangguan obsessive compulsive disorder (OCD) yang diderita.

Sistem Pakar Mendeteksi Gangguan Obsessive Compulsive Disorder Menggunakan Metode Backward Chaining (Hammas Zulfikar lkhsan) 
2. Menampilkan hasil deteksi diagnosa.

3. Menampilkan informasi mengenai tipe-tipe gangguan obsessive compulsive disorder (OCD) dan cara penanganannya.

4. Menampilkan halaman tentang aplikasi sistem pakar dan pengembang aplikasi.

Pada penggunaannya, pengguna berperan untuk memberikan informasi berupa jawaban dari pertanyaan sistem berdasarkan gejala yang dirasakan. Selanjutnya sistem akan bekerja secara otomatis untuk menghasilkan kesimpulan dari gangguan yang diderita sebagai hasil diagnosa.

Penelitian ini bekerja sama dengan seorang dokter psikiater dalam pengumpulan data gangguan Obsessive Compulsive Disorder. Data yang dibutuhkan antara lain tipe gangguan, gangguan, gejala, dan penanganannya. Data gangguan yang didapatkan akan digunakan untuk menyusun rule dari aplikasi sebagai berikut :

Tabel 1 Rule Aplikasi

\begin{tabular}{|c|c|c|}
\hline Rule & Aturan & $\begin{array}{l}\text { CF } \\
\text { rule }\end{array}$ \\
\hline R01 & $\begin{array}{l}\text { IF muncul pikiran yang tidak diinginkan secara terus-menerus AND } \\
\text { pikiran yang muncul menyebabkan kecemasan hingga mengganggu } \\
\text { aktivitas THEN melakukan perilaku yang berulang-ulang (kompulsif) } \\
\text { secara berulang-ulang selama } 1 \text { jam/hari }\end{array}$ & 0.8 \\
\hline R02 & $\begin{array}{l}\text { IF takut terhadap debu, kuman, virus, dan hasil ekskresi tubuh THEN } \\
\text { berusaha menghindari debu, kuman, virus, dan hasil ekskresi tubuh }\end{array}$ & 0.6 \\
\hline R03 & $\begin{array}{l}\text { IF berusaha menghindari debu, kuman, virus, dan hasil ekskresi tubuh } \\
\text { THEN mencuci, mandi, dan membersihkan peralatan yang akan } \\
\text { digunakan secara berulang-ulang }\end{array}$ & 0.4 \\
\hline R04 & $\begin{array}{l}\text { IF mencuci, mandi, dan membersihkan peralatan yang akan digunakan } \\
\text { secara berulang-ulang AND perilaku yang berulang-ulang (kompulsif) } \\
\text { secara berulang-ulang selama } 1 \text { jam/hari THEN gangguan OCD tipe } \\
\text { Washing }\end{array}$ & 0.8 \\
\hline R05 & $\begin{array}{l}\text { IF merasa takut pada kunci pintu, jendela dan pagar rumah saat akan } \\
\text { pergi THEN mengecek kunci pintu rumah secara berulang-ulang }\end{array}$ & 0.8 \\
\hline R06 & $\begin{array}{l}\text { IF merasa takut pada keadaan kompor saat akan pergi THEN } \\
\text { mengecek keadaan kompor secara berulang-ulang }\end{array}$ & 0.6 \\
\hline R07 & $\begin{array}{l}\text { IF merasa takut pada kunci motor/mobil saat akan pergi THEN } \\
\text { mengecek kunci motor/mobil secara berulang-ulang }\end{array}$ & 0.2 \\
\hline R08 & $\begin{array}{l}\text { IF mengecek kunci pintu rumah secara berulang-ulang AND } \\
\text { mengecek keadaan kompor secara berulang-ulang AND mengecek } \\
\text { kunci motor/mobil secara berulang-ulang AND perilaku yang berulang- } \\
\text { ulang (kompulsif) secara berulang-ulang selama } 1 \text { jam/hari THEN } \\
\text { gangguan OCD tipe Checking }\end{array}$ & 0.8 \\
\hline R09 & $\begin{array}{l}\text { IF ingin selalu menata ruang yang berantakan AND senang } \\
\text { mengelompokkan barang berdasarkan warna dan ukuran THEN } \\
\text { terlalu berpikir presisi }\end{array}$ & 0.6 \\
\hline R10 & $\begin{array}{l}\text { IF terlalu berpikir presisi THEN muncul pikiran untuk mengatur } \\
\text { susunan barang sesuai agar dengan pikiran }\end{array}$ & 0.8 \\
\hline R11 & $\begin{array}{l}\text { IF muncul pikiran untuk mengatur susunan barang sesuai dengan } \\
\text { pikiran AND perilaku yang berulang-ulang (kompulsif) secara } \\
\text { berulang-ulang selama } 1 \text { jam/hari THEN gangguan OCD tipe } \\
\text { Symmetry Orderliness }\end{array}$ & 0.8 \\
\hline R12 & $\begin{array}{l}\text { IF merasa sentimental terhadap barang yang dimiliki AND merasa } \\
\text { tidak bisa dan takut untuk membuang atau memberikan barang yang } \\
\text { dimiliki THEN suka menyimpan dan mengoleksi barang yang tidak } \\
\text { dibutuhkan }\end{array}$ & 0.6 \\
\hline
\end{tabular}

TRANSFORMATIKA Vol. 17, No. 1, July 2019: $31-38$ 


\begin{tabular}{|l|l|c|}
\hline R13 & $\begin{array}{l}\text { IF suka menyimpan dan mengoleksi barang yang tidak dibutuhkan } \\
\text { AND perilaku yang berulang-ulang (kompulsif) secara berulang-ulang } \\
\text { selama 1 jam/hari THEN gangguan OCD tipe Hoarding }\end{array}$ & 0.8 \\
\hline R14 & $\begin{array}{l}\text { IF mengecek kunci pintu rumah secara berulang-ulang AND } \\
\text { mengecek keadaan kompor secara berulang-ulang THEN suka } \\
\text { menyimpan dan mengoleksi barang yang tidak dibutuhkan }\end{array}$ & -1 \\
\hline R15 & $\begin{array}{l}\text { IF ingin selalu menata ruang yang berantakan THEN mencuci, mandi, } \\
\text { dan membersihkan peralatan yang akan digunakan secara berulang- } \\
\text { ulang }\end{array}$ & $-0,8$ \\
\hline
\end{tabular}

Setiap rule memiliki nilai CFrule yang digunakan untuk menghitung kemungkinan dideritanya gangguan berdasarkan jawaban dari menggunakan persamaan certainty factor :

1. Rumus untuk rule dengan evidence $E$ tunggal dan hipotesis $H$ tunggal ${ }^{[5]}$

IF $\mathrm{E}$ THEN $\mathrm{H}$ (CF rule)

$\mathrm{CF}(\mathrm{H}, \mathrm{E})=\mathrm{CF}(\mathrm{E}) \times(\mathrm{CF}$ rule)

2. Rumus untuk rule dengan evidence $E$ tunggal dan hipotesis $H$ tunggal[14]

$$
\text { IF } E_{1} \text { AND } E_{2} \ldots \ldots \ldots . . . . A N D E_{n} \text { THEN H (CF rule) }
$$

$\operatorname{CF}(H, E)=\min \left[C F\left(E_{1}\right), C F\left(E_{2}\right), \ldots \ldots, C F\left(E_{n}\right)\right] \times(C F$ rule)

IF $E_{1}$ OR $E_{2} \ldots \ldots \ldots . . . . O R E_{n}$ THEN H (CF rule)

$\mathrm{CF}(\mathrm{H}, \mathrm{E})=\max \left[\mathrm{CF}\left(\mathrm{E}_{1}\right), \mathrm{CF}\left(\mathrm{E}_{2}\right), \ldots \ldots, \mathrm{CF}\left(\mathrm{E}_{\mathrm{n}}\right)\right] \times(\mathrm{CF}$ rule)

3. Rumus untuk rule dengan evidence $E$ tunggal dan hipotesis $\mathrm{H}$ tunggal[ ${ }^{[4]}$

IF $\mathrm{E}_{1}$ THEN $\mathrm{H}$ Rule $1 \quad \mathrm{CF}\left(\mathrm{H}, \mathrm{E}_{1}\right)=\mathrm{CF}_{1}=\mathrm{C}\left(\mathrm{E}_{1}\right) \times(\mathrm{CF}$ rule1)

IF $\mathrm{E}_{2}$ THEN $\mathrm{H}$ Rule $1 \quad \mathrm{CF}\left(\mathrm{H}, \mathrm{E}_{2}\right)=\mathrm{CF}_{2}=\mathrm{C}\left(\mathrm{E}_{2}\right) \times(\mathrm{CF}$ rule2 $)$

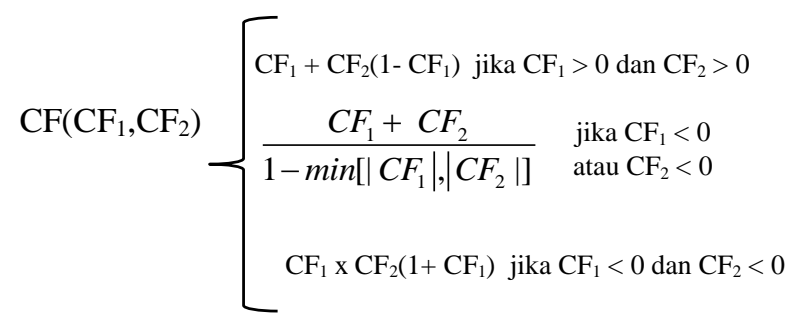

Sistem aplikasi akan menganalisa input yang diberikan oleh pengguna dengan menggunakan metode backward chaining dan akan didapatkan hasil diagnosa apakah pengguna menderita gangguan OCD atau tidak. Kemudian, hasil analisa akan dihitung menggunakan certainty factor untuk menghitung persentase dideritanya gangguan pada pengguna.

\section{Hasil dan Analisa}

Berdasarkan langkah-langkah dari metode Expert System Development Cycle, dihasilkan aplikasi sistem pakar yang digunakan untuk mendeteksi gangguan obsessive compulsive disorder. Aplikasi yang dihasilkan menggunakan metode backward chaining dan metode certainty factor. Metode backward chaining digunakan sebagai mesin inferensi dideritanya tipe gangguan obsessive compulsive disorder pada pasien berdasarkan aturan yang didapatkan dari seorang pakar.

\subsection{Implementasi}

Aplikasi sistem pakar yang dihasilkan berjalan berdasarkan alur kerja (workflow) interaksi antara pengguna dan aplikasi sebagai berikut :

1. Pengguna melakukan login untuk dapat melakukan diagnosa.

2. Sistem akan melakukan validasi pada login pengguna.

3. Apabila login gagal maka pengguna tidak dapat masuk ke halaman deteksi dan otomatis akan kembali ke halaman login.

4. Jika login berhasil maka pengguna akan masuk ke halaman deteksi.

Sistem Pakar Mendeteksi Gangguan Obsessive Compulsive Disorder Menggunakan Metode Backward Chaining (Hammas Zulfikar Ikhsan) 
5. Pengguna mengakses menu deteksi.

6. Sistem menampilkan tipe gangguan obsessive compulsive disorder yang dideteksi aplikasi.

7. Pengguna memilih salah satu tipe gangguan obsessive compulsive disorder untuk dideteksi.

8. Sistem menampilkan pertanyaan yang berisi gejala dari tipe gangguan obsessive compulsive disorder yang dipilih oleh pengguna,

9. Pengguna menjawab pertanyaan sistem dengan cara memilih jawaban yang telah disediakan sistem.

10. Sistem menganalisa jawaban yang telah dipilih oleh pengguna menggunakan metode backward chaining berdasarkan rule.

11. Apabila tipe gangguan obsessive compulsive disorder terdeteksi, sistem akan menghitung besar kemungkinan dideritanya tipe gangguan obsessive compulsive disorder menggunakan metode certainty factor.

12. Apabila tidak terdeteksi, sistem akan menampilkan keluaran bahwa pengguna tidak menderita tipe gangguan obsessive compulsive disorder yang dipilih.

13. Apabila pengguna akan melakukan diagnosa lagi, sistem menampilkan halaman awal menu deteksi.

14. Pengguna melakukan logout.

\subsection{Antarmuka}

Tampilan antarmuka sistem menggunakan bahasa pemrograman html dan PHP yang berjalan pada localhost. Antarmuka aplikasi yaitu halaman beranda, halaman dokter dan halaman deteksi.

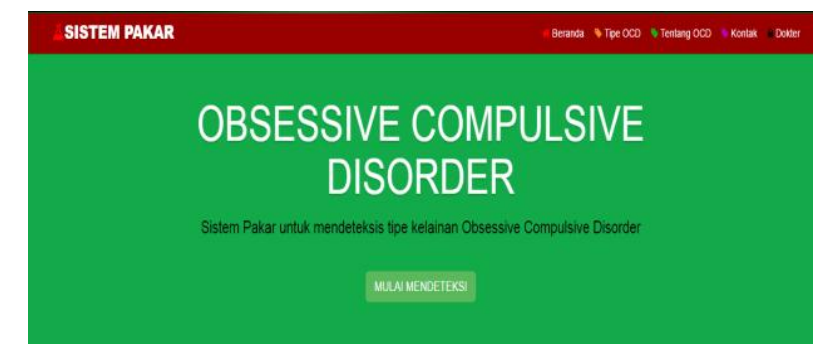

Gambar 2 tampilan beranda

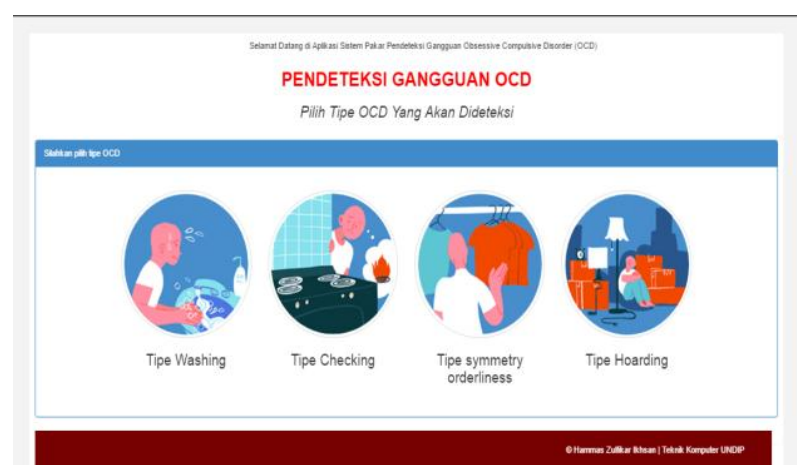

Gambar 6 Tampilan menu awal deteksi

TRANSFORMATIKA Vol. 17, No. 1, July 2019: $31-38$ 


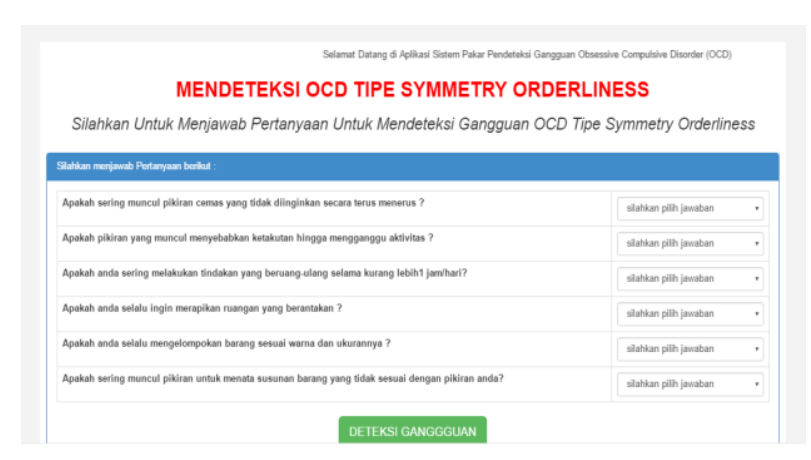

Gambar 7 Tampilan menu deteksi

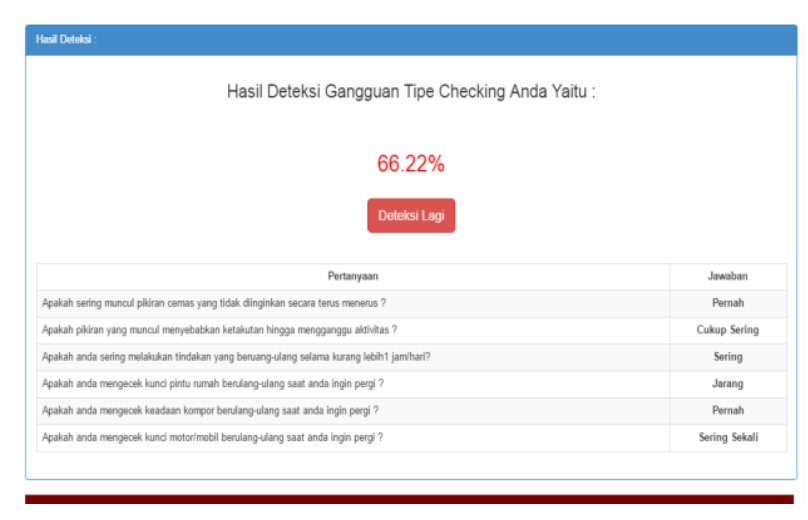

Gambar 8 Tampilan menu deteksi

\subsection{Hasil Pengujian}

Pada pengujian pengujian sistem aplikasi, dilakukan pengujian untuk membuktikan bahwa aplikasi sistem pakar yang dibuat telah sesuai dengan data yang diberikan oleh pakar.

Tabel 4 Hasil Pengujian Sistem

\begin{tabular}{|c|c|c|c|c|}
\hline No & Tipe Gangguan & $\begin{array}{l}\text { Jawaban } \\
\text { Pengguna }\end{array}$ & $\begin{array}{l}\text { Hasil Analisa } \\
\text { Sistem }\end{array}$ & $\begin{array}{l}\text { Validasi } \\
\text { Pakar }\end{array}$ \\
\hline 1 & Tipe Washing & $\begin{array}{cc}1 . & \mathrm{CS}(0,6) \\
2 . & \mathrm{J}(0,4) \\
\text { 3. } & \mathrm{S}(0,8) \\
\text { 4. } & \mathrm{P}(0,2) \\
5 . & \mathrm{SS}(1,0)\end{array}$ & $86,29 \%$ & Benar \\
\hline 2 & Tipe Washing & $\begin{array}{cc}\text { 1. } & \mathrm{P}(0,2) \\
\text { 2. } & \mathrm{J}(0,4) \\
\text { 3. } & \mathrm{J}(0,4) \\
\text { 4. } & \mathrm{J}(0,4) \\
\text { 5. } & \mathrm{TP}(0,0)\end{array}$ & $\begin{array}{c}\text { Tidak Menderita } \\
\text { Gangguan }\end{array}$ & Benar \\
\hline 3 & Tipe Checking & $\begin{array}{cc}\text { 1. } & \mathrm{P}(0,2) \\
\text { 2. } & \mathrm{CS}(0,6) \\
\text { 3. } & \mathrm{S}(0,8) \\
\text { 4. } & \mathrm{J}(0,4) \\
\text { 5. } & \mathrm{P}(0,2) \\
\text { 6. } & \mathrm{SS}(1,0)\end{array}$ & $66,22 \%$ & Benar \\
\hline
\end{tabular}

Sistem Pakar Mendeteksi Gangguan Obsessive Compulsive Disorder Menggunakan Metode Backward Chaining (Hammas Zulfikar lkhsan) 


\begin{tabular}{|c|c|c|c|c|}
\hline 4 & Tipe Checking & $\begin{array}{cc}\text { 1. } & \mathrm{SS}(1,0) \\
\text { 2. } & \mathrm{CS}(0,6) \\
\text { 3. } & \mathrm{S}(0,8) \\
\text { 4. } & \mathrm{TP}(0,0) \\
\text { 5. } & \mathrm{TP}(0,0) \\
\text { 6. } & \mathrm{P}(0,2)\end{array}$ & $\begin{array}{c}\text { Tidak Menderita } \\
\text { Gangguan }\end{array}$ & Benar \\
\hline 5 & $\begin{array}{c}\text { Tipe Symmetry } \\
\text { Orderliness }\end{array}$ & $\begin{array}{cc}\text { 1. } & \mathrm{S}(0,8) \\
\text { 2. } & \mathrm{CS}(0,6) \\
\text { 3. } & \mathrm{J}(0,4) \\
\text { 4. } & \mathrm{P}(0,2) \\
\text { 5. } & \mathrm{P}(0,2) \\
\text { 6. } & \mathrm{J}(0,4) \\
\end{array}$ & $73,86 \%$ & Benar \\
\hline 6 & $\begin{array}{c}\text { Tipe Symmetry } \\
\text { Orderliness }\end{array}$ & $\begin{array}{cc}1 . & \mathrm{P}(0,2) \\
\text { 2. } & \mathrm{S}(0,8) \\
\text { 3. } & \mathrm{SS}(1,0) \\
\text { 4. } & \mathrm{P}(0,2) \\
\text { 5. } & \mathrm{TP}(0,0) \\
6 . & \mathrm{J}(0,4)\end{array}$ & $\begin{array}{c}\text { Tidak Menderita } \\
\text { Gangguan }\end{array}$ & Benar \\
\hline 7 & Tipe Hoarding & $\begin{array}{cc}\text { 1. } & \mathrm{CS}(0,6) \\
\text { 2. } & \mathrm{J}(0,4) \\
\text { 3. } & \mathrm{SS}(1,0) \\
\text { 4. } & \mathrm{P}(0,2) \\
\text { 5. } & \mathrm{J}(0,4) \\
\text { 6. } & \mathrm{CS}(0,6)\end{array}$ & $68,88 \%$ & Benar \\
\hline 8 & Tipe Hoarding & $\begin{array}{cc}\text { 1. } & \mathrm{J}(0,4) \\
\text { 2. } & \mathrm{CS}(0,6) \\
\text { 3. } & \mathrm{S}(0,8) \\
\text { 4. } & \mathrm{TP}(0,0) \\
\text { 5. } & \mathrm{J}(0,4) \\
\text { 6. } & \mathrm{CS}(0,6)\end{array}$ & $\begin{array}{c}\text { Tidak Menderita } \\
\text { Gangguan }\end{array}$ & Benar \\
\hline
\end{tabular}

TP=Tidak Pernah;P=Pernah;J=Jarang;CS=Cukup Sering;S=Sering;SS=Sering Sekali

Hasil dari pengujian sistem dan pengujian validasi oleh pakar menghasilkan bahwa sistem dari aplikasi berhasil menampilkan kemungkinan dideritanya tipe gangguan OCD yang dideteksi berdasarkan jawaban pengguna telah sesuai dengan pengetahuan pakar. Pada pengujian ini, sistem pendeteksi menghasilkan persentase kemungkinan tipe washing yaitu $86,29 \%$, tipe checking yaitu $66,22 \%$, tipe symmetry orderliness yaitu $73,86 \%$, dan tipe hoarding yaitu $68,88 \%$. Selain hasil tadi, sistem juga menghasilkan output apabila penderita tidak menderita gangguan OCD pada setiap tipe yang dideteksi.

\section{Kesimpulan}

Kesimpulan dari penelitian Tugas Akhir ini adalah sebagai berikut:

1. Dari penelitian yang telah dilakukan, dihasilkan aplikasi sistem pakar yang dapat mendeteksi gangguan obsessive compulsive disorder (OCD) dengan menggunakan metode backward chaining dan metode certainty factor.

2. Pada pengujian black box ditunjukan bahwa setiap fungsi pada aplikasi sistem pakar mendeteksi gangguan obsessive compulsive disorder (OCD) dapat berjalan seperti fungsinya.

3. Pengujian validasi sistem dilakukan oleh pakar, dihasilkan aplikasi berhasil menampilkan kemungkinan dideritanya tipe gangguan OCD yang dideteksi berdasarkan jawaban pengguna. Hasil pengujian telah sesuai dengan pengetahuan pakar dan penghitungan manual.

\section{References}

TRANSFORMATIKA Vol. 17, No. 1, July 2019: $31-38$ 
[1] Amdan, P.Y., J.R. Suminar., Aristi, Nindi. 2012. Konstruksi ldentitas Penyandang Obsessive Compulsive Disorder. Bandung : Jurnal Mahasiswa Universitas Padjadjaran, vol.1., no.1.

[2] Guesehat. OCD, Gangguan Psikologi Berawal dari Kecemasan. "https://www.guesehat.com/ocd-gangguan-psikologis-berawal-dari-kecemasan" diakses tanggal 18 Oktober 2018.

[3] Mukhtar, N., Samsudin. 2015. Sistem Pakar Diagnosa Dampak Penggunaan Softlens Menggunakan Metode Backward Chaining. Riau : Jurnal Buana Informatika, vol.6., no. 1, hal. 21-30.

[4] Ikorasaki, Frans. 2015. Sistem Pakar Mendiagnosa Penyakit Pada Tulang Dengan Menggunakan Metode Certainty Factor. Medan : Seminar Nasional Informatika.

[5] Daroji. Sistem Pakar Diagnosa Penyakit Sapi Menggunakan Metode Backward Chaining dan Certainty Factor. Yogyakarta : Teknik Informatika STMIK EI Rahma Yogyakarta.

[6] Sembiring, Hery Hadinata. 2014. Implementasi Sistem Pakar Diagnosa Gangguan Kepribadian Menggunakan Metode Certainty Factor dan Metode Fuzzy. Medan : Skripsi. Fakultas IImu Komputer dan Teknologi Informasi Universitas Sumatra Utara Medan.

[7] Anisa, Ary. 2016. Terapi Kognitif Untuk Menangani Gangguan Obsesif Kompulsif : Studi Kasus. Malang : Seminar ASEAN $2^{\text {nd }}$ PSYCHOLOGY \& HUMANITY.

[8] Durrand, V.Mark, Barlow, David H. 2006 Intisari Psikologi Abnormal. Edisi ke 4. Diterjemahkan oleh : Helly Prajitno Soetjipto dan Sri Mulyantini. Yogyakarta : Pustaka Pelajar.

[9] Ibrahim, Ayub Sani. 2012. Panik, Neurosis dan Gangguan Cemas. Tangerang : Jelajah Nusa.

[10] Mu'Minat, Uti Ayu. 2010. Obsessive-Compulsive Disorder Tokoh Howard Hughes Dalam Film The Aviator. Semarang : Skripsi. Universitas Diponegoro Semarang.

[11] Kusrini. 2006. Sistem Pakar Teori dan Aplikasi. Yogyakarta : Penerbit ANDI.

[12] Nugroho, Arief Kelik, Wardoyo, Retantyo. 2013. Sistem Pakar Menggunakan Teorema Bayes Untuk Mendiagnosa Penyakit Kehamilan. Yogyakarta : Berkala MIPA.

[13] Sutojo, M., Edy, M., Suhartono, V. 2011. Kecerdasan Buatan. Yogyakarta : Penerbit ANDI.

[14] Nur, A., Ikhsan, D., Ariadi, I., Rosyid, M.B., Ridwan, M. 2017. Perancangan Sistem Pakar Menggunakan Metode Backward Chaining Untuk Diagnosa Penyakit Pada Hewan Ternak Sapi Berbasis Web. Yogyakarta : Seminar Nasional Teknologi Informasi dan Multimedia.

[15] Kadir, Abdul. 1999. Konsep dan Tuntunan Praktis Basis Data. Yogyakarta : Penerbit ANDI. 